\title{
On the distribution of silicic acid as a frontal zone tracer in the Indian sector of the Southern Ocean*
}

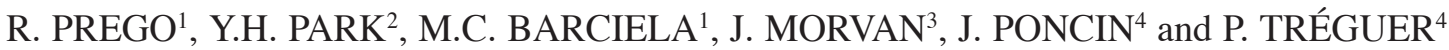 \\ ${ }^{1}$ Instituto de Investigaciones Marinas (CSIC). Eduardo Cabello, 6. 36208 Vigo, Spain. (e-mail: prego@iim.csic.es) \\ ${ }^{2}$ Muséum National d'Histoire Naturelle. 43 rue Cuvier. 75231 Paris, France. \\ ${ }^{3}$ Ecole Nationale Supérieure de Chimie. av. Général Leclerc. 35700 Rennes, France. \\ ${ }^{4}$ Institute d'Etudes Marins (UBO). 6, av. Le Gorgeu. 29287 Brest, France.
}

\begin{abstract}
SUMMARY: The subantarctic frontal zone surveyed during the April-May 1991 SUZIL cruise in the Crozet-KerguelenAmsterdam area shows a strong horizontal (north to south) gradient of dissolved silicate, increasing with depth, from 5 to $10 \mu \mathrm{molSi} \mathrm{kg}{ }^{-1}$ at $100 \mathrm{~m}$, and 10 to $70 \mu \mathrm{molSi} \mathrm{kg}{ }^{-1}$ at $600 \mathrm{~m}$. The northern limit of this frontal zone, which is formed by the confluence of the Subtropical and Subantarctic Fronts, is delimited at the surface by the $2 \mu \mathrm{molSi} \mathrm{kg}^{-1}$ silicate isoline. Silicate-salinity diagrams also allow different water regimes to be positioned relative to the frontal zone. This sloping interface is between two water bodies, one to the north with more saline subtropical waters of less concentrated silicate than the southern one, corresponding to subantarctic waters which are less saline and richer in silicate. It is concluded that dissolved silicate can be used as a useful tracer of frontal zone water masses in the Indian sector of the Southern Ocean, providing a sound complement to other hydrographic data.
\end{abstract}

Key words: silicate, tracer, frontal zone, silicate-salinity diagram, Crozet Basin, Southern Ocean.

\section{INTRODUCTION}

The Subtropical Front (STF) is considered the northern limit of the Subantarctic Surface Waters (Orsi et al., 1995). In the central Indian sector of the Southern Ocean, both the STF and the Subantarctic Front (SAF) are found north of the Crozet and Kerguelen Plateaus, forming an unique frontal zone (Gamberoni et al., 1982). In this frontal zone, the advection of water masses is driven by the Antarctic Circumpolar Current (ACC). The single-band frontal structure observed in the ACC is most pro-

\footnotetext{
*Received August 7, 1998. Accepted February 9, 1999.
}

nounced north of Kerguelen, where it is concentrated along the shelf edge within a narrow frontal zone of about $200 \mathrm{~km}$ (Park et al., 1991). In this Crozet Basin area, the Polar Front (PF) is completely separated from the frontal zone.

The confluence of the Agulhas Return Current with the ACC at the entrance of the Crozet Basin, as well as the topographic control of the current flow by the Crozet and Kerguelen Plateaus are responsible for such a particular regional ACC frontal structure (Park et al., 1993a). The hydrography of the area has been well studied on the basis of the distribution of temperature, salinity and dissolved oxygen. 


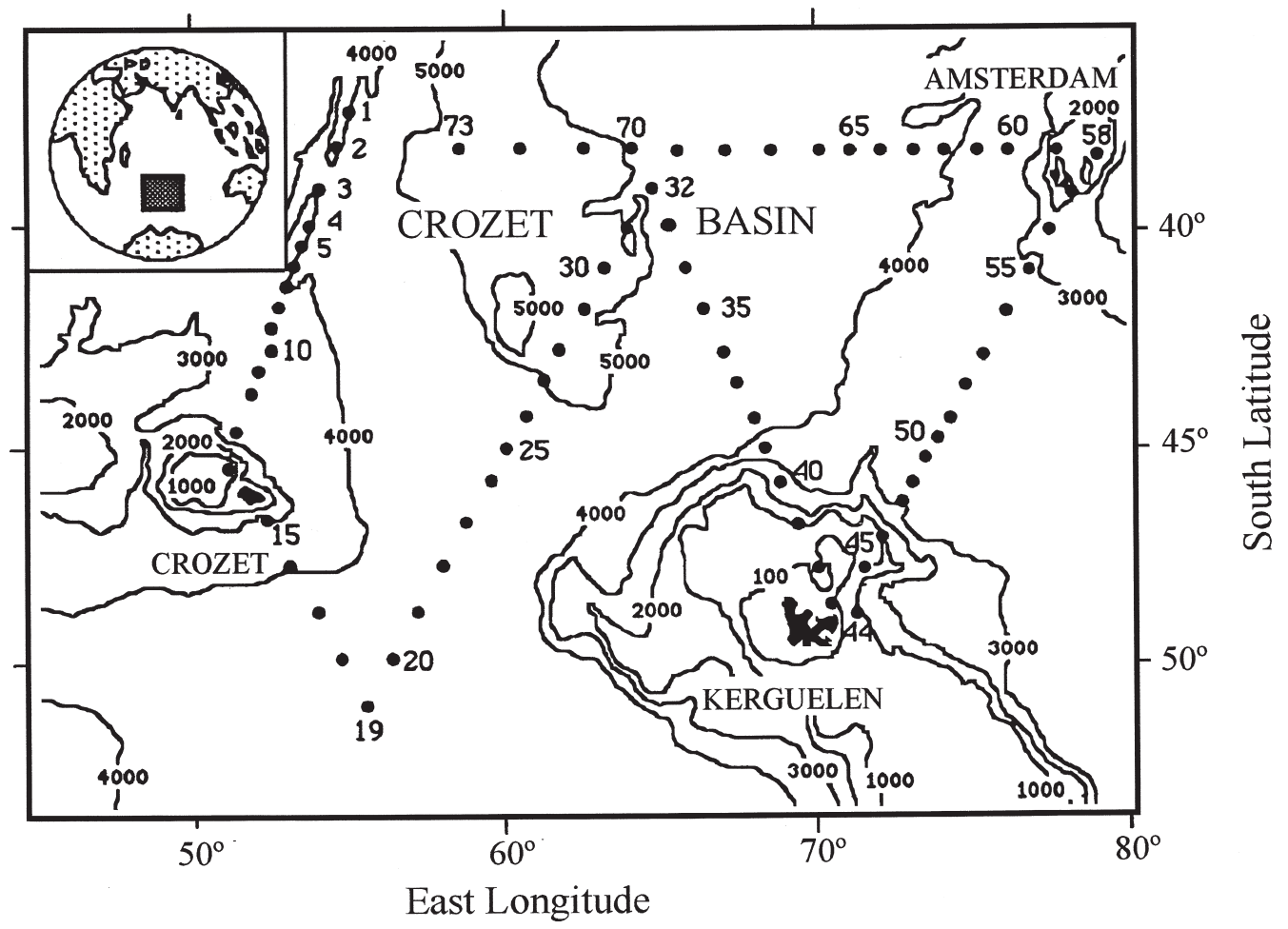

FIG. 1. - Position of stations sampled in the Indian sector of the Southern Ocean during the April-May 1991 SUZIL cruise. Depth contours are in meters.

The nutrient richness of the Southern Ocean (Jones et al., 1990) and the low nutrient concentrations in the water masses to the north of the ACC is the reason for a strong lateral gradient of nutrients, the direction of a gradient is from high to low concentration (Lujeharms et al., 1985; Bennekom et al., 1988). The nitrate and phosphate concentrations change slowly close to the Antarctic convergence areas, but dissolved silicate concentration does so more rapidly (Walsh, 1971; Holm-Hansen et al., 1977). Near the PF in the Indian sector of the Southern Ocean (Jones et al., 1990), a high horizontal silicate gradient occurs in comparison to the much smaller change of the other two main nutrient salts, i.e. nitrate and phosphate (Le Jehan and Tréguer, 1983; Le Corre and Minas, 1983). For these reasons, silicate would be an appropriate tracer of the frontal zones in the Indian sector of the Southern Ocean, as has been highlighted in the Atlantic Ocean by Cooper (1952), and later by Metcalf (1969).

The aim of this paper is to describe the distribution of dissolved silicate in the upper $600 \mathrm{~m}$ of the Crozet Basin area and to propose the silicate-salinity diagram as a useful tool in the position of the frontal zone (STF+SAF).

\section{DATA AND METHODS}

Salinity, temperature and dissolved silicate data were obtained during the April-May 1991 SUZIL cruise, on board the French M/V Marion Dufresne. The cruise was carried out in the Indian sector of the Antarctic Ocean (Crozet, Kerguelen and New Amsterdam Islands, Fig.1). Water samples were taken with rosette using $12 \mathrm{~L}$ Niskin bottles mounted on a Neil Brown CTD and General Oceanic rosette, at the surface in all the stations and at depths of 50, 100, 150, $200,250,300,400,500$ and $600 \mathrm{~m}$ on the stations 1931 and at 50, 100, 250 and $500 \mathrm{~m}$ on stations 32-58.

Analyses of dissolved silicate were carried out on all samples soon after the rosette was brought on board. Non-filtered water samples were analyzed using a Technicon AAII autoanalyser, following the method given by Tréguer and Le Corre (1975). The overall measurement error for silicate is estimated as $\pm 0.1 \mu \mathrm{molSi} \mathrm{kg}{ }^{-1}$ based on duplicate sample analyses. Potential temperature was taken from the CTD record and salinity was determined on board using a Guildline "Portasal" salinometer, with water samples taken at the aforementioned depths. The calibrated CTD data are reported in Park et al. (1993b), and an analysis of the data in terms of water masses 
and circulation is made in Park et al. (1993a). The data for salinity, temperature and dissolved silicate in discrete water samples taken in the upper $600 \mathrm{~m}$ appear in Lasalle (1991).

\section{RESULTS}

\section{Surface dissolved silicate distribution}

The surface concentration of dissolved silicate vary from 1 to $18 \mu \mathrm{molSi} \mathrm{kg}{ }^{-1}$ (Fig. 2), in accordance with Le Corre and Minas (1983) and LeJehan
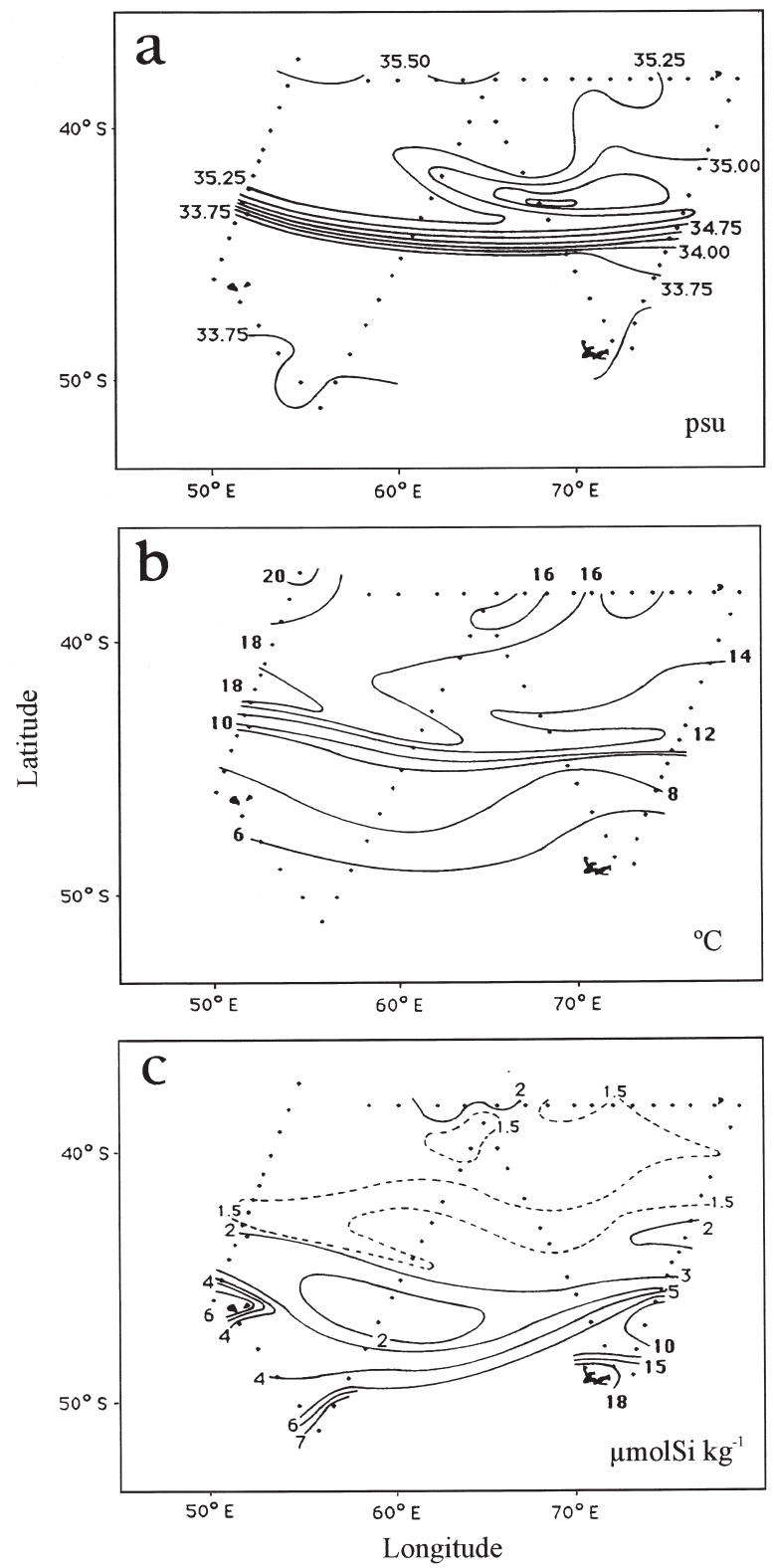

FIG. 2. - Surface isolines of (a) salinity; (b) temperature; and (c) dissolved silicate in the surveyed area during the April-May 1991 SUZIL cruise.
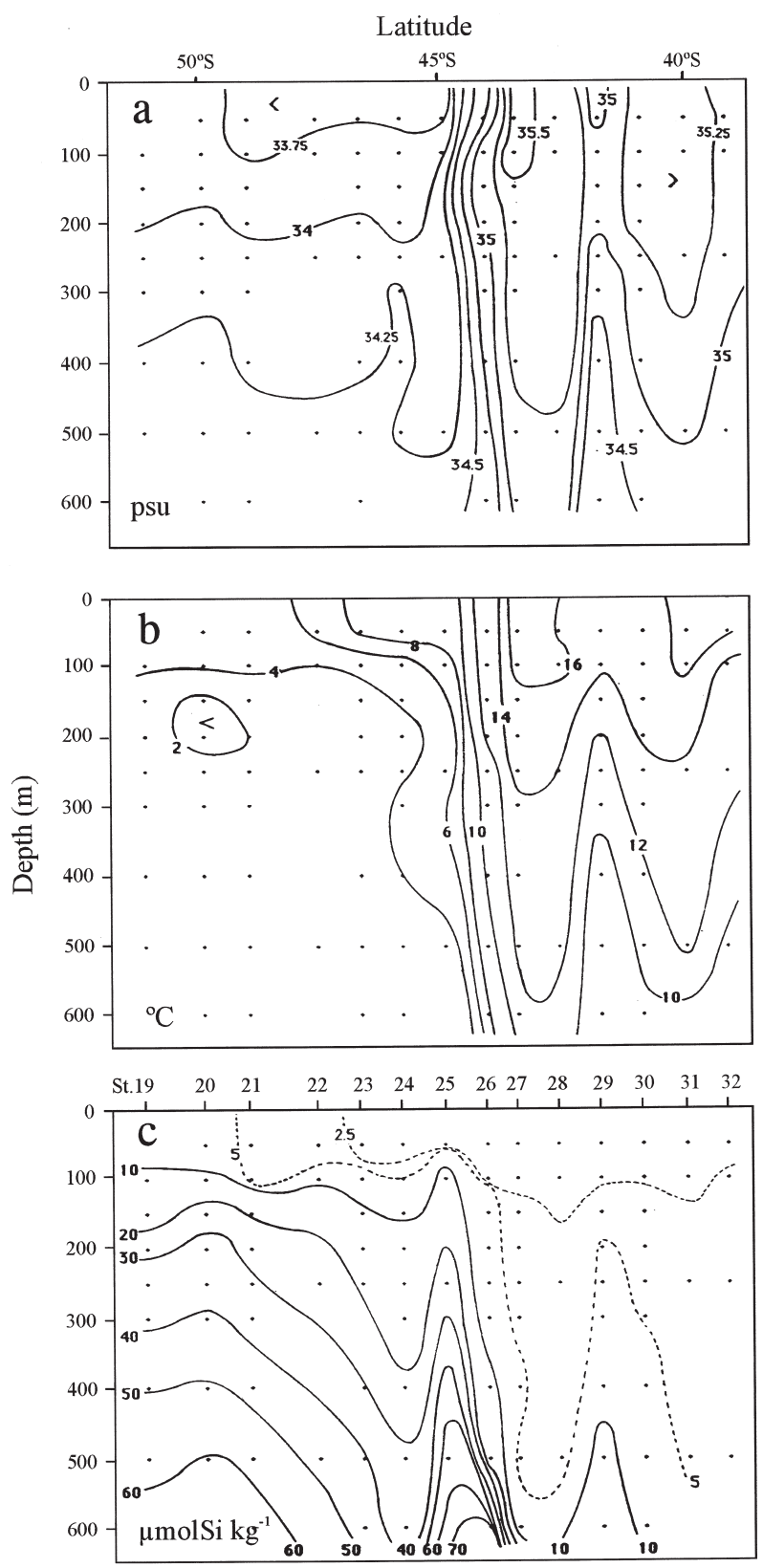

FIG. 3. - Vertical distribution of (a) salinity; (b) potential temperature; and (c) dissolved silicate along the section between stations 19 and 32 (Fig.1).

and Treguer (1985). The highest values appear in the southernmost stations $\left(7 \mu \mathrm{molSi} \mathrm{kg}{ }^{-1}\right.$ near stations 18, 19 and 20) and around Kerguelen and Crozet

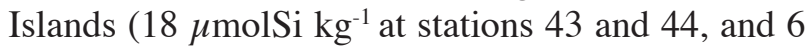
$\mu$ molSi kg-1 at stations 14 and 15). The larger horizontal gradients are also associated with these highsilicate content regions.

The PF, defined as a northern limit of the subsurface temperature minimum of $2^{\circ} \mathrm{C}$ at around $200 \mathrm{~m}$ depth (Emery, 1977), is illustrated in Fig. 3 between stations 20 and 21 at about $50^{\circ} \mathrm{S}$. But, the PF just 
northeast of Kerguelen is shifted further north to about $47^{\circ} \mathrm{S}$. While surface temperature and salinity associated with the PF in the Crozet Basin area correspond to about $5^{\circ} \mathrm{C}$ and 33.75 psu (Park et al., 1991), their spatial distributions (Fig. 2) do not clearly indicate the position of the front. However, a pronounced silicate gradient, with silicate concen-

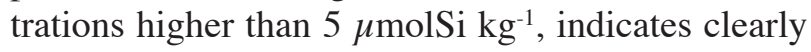
the surface expression of the PF. The highest silicate

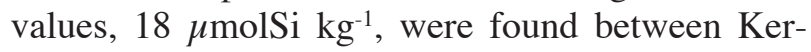
guelen and Crozet Islands.

Further north are the STF and SAF regions. The STF can be defined by a sharp rise in surface salinity above 34.9 psu (Deacon, 1982) or by subsurface temperature and salinity ranges of $4-8^{\circ} \mathrm{C}$ and $34.6-35.0 \mathrm{psu}$ at $200 \mathrm{~m}$ depth. As indicated by Orsi et al. (1995), there is a narrow transition between warm and saline surface waters of the subtropical regime and colder and fresher subantarctic waters. The SAF can be defined by 4$8^{\circ} \mathrm{C}$ and 34.1-34.5 psu at $200 \mathrm{~m}$ (Park et al., 1993a). Both fronts are very near one to the other forming a single-band frontal zone, as can be seen by the closely packed surface isotherms and isohalines (Fig. 2). Between $75 \%$ and $80 \%$ of the ACC transport in the Crozet Basin area is associated with this frontal zone (Park et al., 1993a). This zone encompasses stations 810, 25-27, 36-39 and 49-51, the northern boundary of which corresponds approximately with the $2 \mu \mathrm{molSi}$ $\mathrm{kg}^{-1}$ isoline of silicate at the surface (Fig. 2).

The Agulhas Return Current advects warm and low silicate water into the study area along the northern boundary of the frontal zone, i.e. the northern part of the Crozet Basin. In Fig. 2, the Agulhas influence can be evidenced to the north of the frontal zone by (Park et al., 1993a) high temperatures $\left(>16^{\circ} \mathrm{C}\right)$ and salinities (35.3 psu), especially in the western half of the basin. Surface silicate concentrations associated with the subtropical Agulhas water

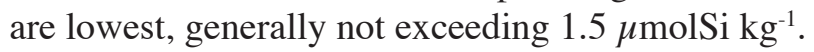

\section{Vertical dissolved silicate structure}

The vertical property structures in the upper 600 $\mathrm{m}$ of the section formed by stations 19 to 32 are shown in Fig. 3. This section was chosen because it is located far from island influences and also due to the greater number of sampling points in the vertical. The frontal zone (STF/SAF) is clearly marked between stations 25 and 27 by a band (between $43.6^{\circ}$ to $45.2^{\circ} \mathrm{S}$ ) of strong gradient, separating warm, saline and silicate-poor subtropical water from cold, fresh and silicate-rich subantartic water.
The most remarkable features in silicate distribution north of the frontal zone are the very low con-

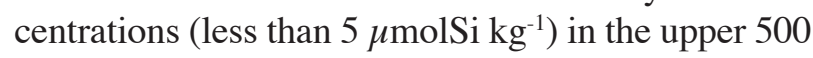
$\mathrm{m}$ and a low vertical silicate gradient in comparison with the silicate concentrations south of station 25 (Fig. 3). The maximum concentration there is only about $15 \mu \mathrm{molSi} \mathrm{kg}^{-1}$ at $600 \mathrm{~m}$ depth. This shows a striking contrast to the situation south of the frontal zone where strong silicate stratification begins just underneath the surface mixed layer, with values varying from $10 \mu \mathrm{molSi} \mathrm{kg} \mathrm{kg}^{-1}$ at $100 \mathrm{~m}$ depth to a maximum of about $70 \mu$ molSi $\mathrm{kg}^{-1}$ at $600 \mathrm{~m}$ depth.

There are two exceptions to this general description of silicate distribution:

(1) station 24, is located south of the frontal zone but shows lower silicate concentrations (and surface salinity, $<33.75$ psu) than nearby stations.

(2) station 29 , is located north of the frontal zone but has higher silicate concentrations than the surrounding stations (Fig.2). In this station, the subsurface silicate isolines also correspond with isotherms and isohalines (Fig.3). This feature is probably related to an eddy, a feature that Park et al. (1993a) have pointed out in other cruises.

\section{DISCUSSION}

The dissolved silicate in the Indian sector of the Southern ocean provides useful information for positioning the subantarctic frontal zone. During the end of summer (SUZIL cruise carried out during autumn): (1) the diatom populations are not abundant (Jacques et al., 1979); (2) the primary production is low (El-Sayed and Jitts, 1973), similar to oligotrophic seas (Jacques and Minas, 1981); and (3) the surface silicate has a non-conservative behaviour (Le Jehan and Tréguer, 1983; 1985). Hovewer, the large increase of silicate concentration (horizontal, Fig. 2; vertical, Fig. 3), makes the silicate an useful chemical tracer for the frontal zone in the cruise area.

\section{Silicate-salinity diagrams}

Further information on the surface structure of the frontal zone can be obtained, as shown in Fig.4. In a potential temperature-salinity $(\theta-S)$ diagram, two clusters of points clearly define stations north and south of the frontal zone. The silicate-salinity $(\mathrm{Si}-\mathrm{S})$ and potential temperature-silicate $(\theta-\mathrm{Si})$ diagrams show the points seen in the $\theta-S$ diagram 


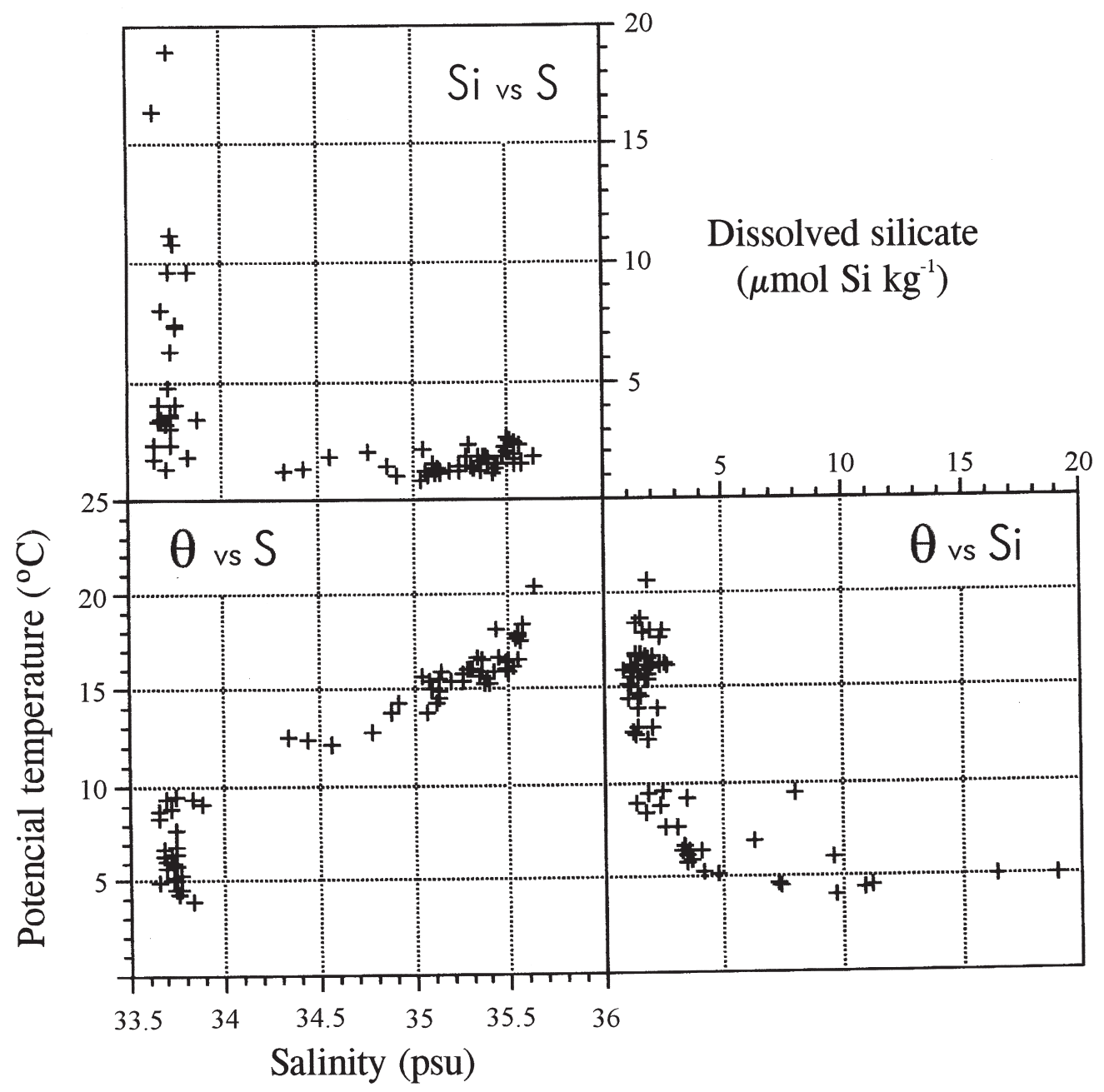

FIG. 4. - Surface station data shown in Fig. 2: potential temperature-salinity $(\Theta-S)$; potential temperaturesilicate $(\Theta-\mathrm{Si})$; and silicate-salinity $(\mathrm{Si}-\mathrm{S})$.

appear with a new perspective. In the Si-S diagram, they appear separated, while in the $\theta-\mathrm{Si}$ diagram they are grouped within a narrow band of dissolved silicate. As both silicate scales in $\theta-\mathrm{Si}$ and $\mathrm{Si}-\mathrm{S}$ are the same, the $\mathrm{Si}-\mathrm{S}$ diagram is more suitable for separating the different water masses across the frontal zone than the $\theta$-Si diagram.

Surface data in the study area (Fig. 2) show in the Si-S diagram (Fig. 4) three distinct zones which correspond to:

1) stations with silicate between 1 and $3 \mu \mathrm{molSi}$ $\mathrm{kg}^{-1}$ and surface salinity above $35.0 \mathrm{psu}$. These stations are found north of the frontal zone (st. 1-8, 2735,37 and 52-73);

2) stations with silicate above $2 \mu \mathrm{molSi} \mathrm{kg}{ }^{-1}$ and surface salinities below 34.0 psu. They are found south of the frontal zone (st. 10, 11, 13-22, 40-47 and 49);

3) intermediate stations within the frontal zone.
These frontal zone stations show a silicate content of

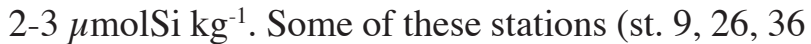
and 51) are influenced by seawater north of the frontal zone, with salinities between 34.0 and 35.0 psu. Other stations (st. 12, 23-25, 39 and 48) are affected by seawater south of the frontal zone, with salinities of below 34.0 psu.

The sets pointed out on the Si-S diagram (Fig. 5) show four different groups of data: (1) north; (2) south; (3) within the frontal zone; and (4) Kerguelen continental shelf. Towards the south of the frontal zone, linear regression between silicate-salinity (Fig. 5) supports mixing between two water types.

Data points of stations 42 and 43 (Fig. 5) are clustered outside of this regression line, around a SiS point: $18 \mu \mathrm{molSi} \mathrm{kg}{ }^{-1}, 33.7 \mathrm{psu}$. These stations, located on the continental shelf (upper $150 \mathrm{~m}$ ) just north of Kerguelen, with narrow ranges of dissolved silicate (16-19 $\left.\mu \mathrm{molSi} \mathrm{kg}^{-1}\right)$, salinity (33.58-33.72 


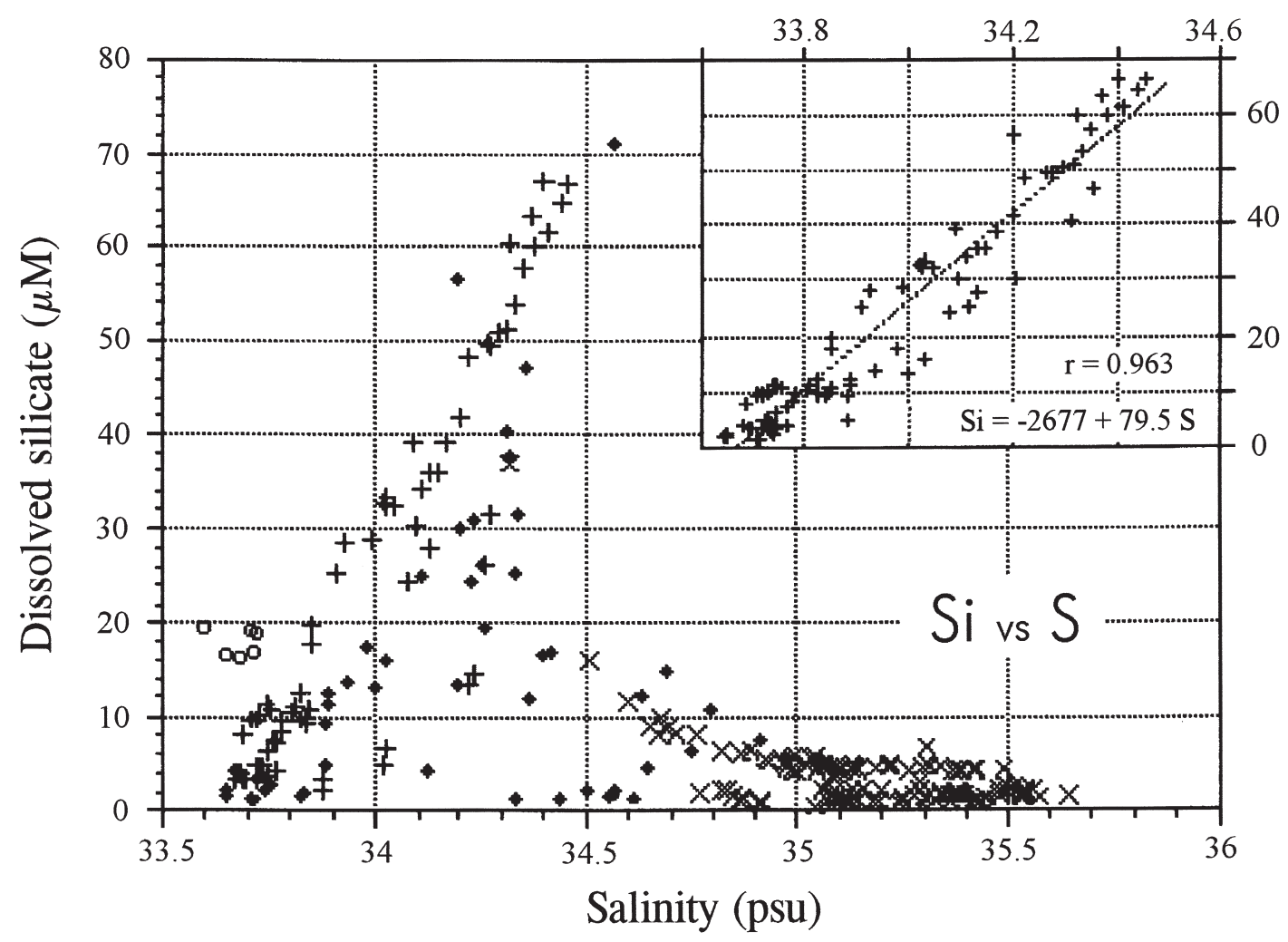

FIG. 5. - Silicate-salinity (Si-S) diagram of the whole SUZIL data. Key to the symbols: $x$ the stations north of the frontal zone; + the stations south of the frontal zone; the stations within of the frontal zone; o the stations 42 and 43 (over the continental shelf north of Kerguelen).

psu) and temperature $\left(4.8-5.1^{\circ} \mathrm{C}\right)$ receive freshwater inputs from the Kerguelen Islands and show the vertical mixing from the surface to the bottom caused by the autumn weather.

\section{CONCLUSIONS}

The distribution of dissolved silicate in the Crozet Basin, as observed during the April-May 1991 SUZIL cruise, provide useful information for locating and describing the subantarctic frontal zone.

Used in conjuntion with temperature and salinity, dissolved silicate is a useful tracer for identifying the frontal zone water masses in the Indian sector of Antarctic Ocean. Here, the silicate-salinity diagrams are shown to be useful tools for describing different water masses.

\section{ACKNOWLEDGEMENTS}

We would like to express our thanks to Christian Loudes, captain of M/V Marion Dufresne and his crew for their professional assistance during the
SUZIL 1991 cruise. Our thanks are also due to the other scientists who took part in the cruise, particularly Lucien Gamberoni and Jean Louis Lasalle. Thanks also to the Terres Australes Antarctiques Françaises, especially to Claude Chaufriasse, for help in making this work possible, to Angeles García for setting out the figures and to Ian Emmett for the text revision. This paper is supported by the Spanish project, ANT90-123-E, financed by the Comisión Interministerial de Ciencia y Tecnología.

\section{REFERENCES}

Bennekom, van A.J., G.W. Berger, S.J. van Der Gaast and R.T.P. De Vries. - 1988. Primary productivity and the silica cycle in the southern ocean (Atlantic sector). Palaeogeography, Palaeoclimatology Palaeoecology, 76: 19-30.

Cooper, L.H. - 1952. Factors affecting the distribution of silicate in the North Atlantic Ocean and the formation of North Atlantic Deep Water. J. mar. biol. Ass. U.K., 30: 511-526.

Deacon, G.E.R. - 1982. Physical and biological zonation in the Southern Ocean. Deep-Sea Res., 29: 1-15.

El-Sayed, S.Z. and H.R. Jitts. - 1973. Phytoplankton production in the Southeastern Indian Ocean. In: D. Zeitzschel (ed): Biology of the Indian Ocean, pp. 13-142. Springer-Verlag, Berlin, .

Emery, W.J. - 1977. Antarctic polar frontal zone from Australia to the Drake Passage. J. Phys. Oceanogr., 7: 811-822.

Gamberoni, L., J. Geronimi, P. Jeannin, and J.F. Murail. - 1982. Study of frontal zones in the Crozet-Kerguelen region. Oceanol. Acta, 5: 289-299. 
Holm-Hansen, O., S.Z. El-Sayed, G.A. Franceschini and R. Cuhel. - 1977. Primary production and the factors controlling phytoplankton growth in the Southern ocean. In: G.A. Llano (ed): Adaptations within Antarctic ecosystems, pp. 11-50. IIIrd SCAR Symposium Antarct. Biol. Smithsonian Inst.

Jacques, G., C. Descolas, J.R. Grall and A. Sournia. - 1979. Distribution du phytoplancton dans la partie antarctique de l'Océan Indien en fin d'été. Int. Rev. Gesamten Hydrobiol., 64: 609628.

Jacques, G. and M. Minas. - 1981. Production primaire dans le secteur indien de l'océan Antarctique en fin d'été. Oceanol. Acta, 4: 33-41.

Jones, E.P., D.M. Nelson and P. Treguer. - 1990. Chemical Oceanography. In: Polar Oceanography, Part B: Chemistry, Biology and Geology, pp. 407-476. Academic Press, London,

Lasalle, J.L. - 1991. Distribution des silicates dans la zone frontale de l'océan Indien. Situation d'automne. Rapport de Stage. Ecole National Supérieure de Chimie de Rennes. Rennes.

Le Corre, P. and H.J. Minas. - 1983. Distribution et évolution des éléments nutritifs dans le secteur indien de l'Océan Antarctique en fin de période estivale. Oceanol. Acta, 6: 365-381.

Le Jehan, S. and P. Treguer. - 1983. Uptake and regeneration $\mathrm{Si}: \mathrm{N}: \mathrm{P}$ ratios in the Indian sector of the Southern Ocean. Pol. Biol., 2: 127-136.

Le Jehan, S. and P. Treguer. - 1985. The distribution of inorganic nitrogen, phosphorus, silicon and dissolved organic matter in surface and deep waters of the Southern Ocean. In : W.R. Siegfried, P.R. Condy and R.M. Laws (eds): Antarctic Nutrient cycles and food webs, pp. 22-29. Springer-Verlag, Berlín.

Lutjeharms, J.R., N.M. Walters and B.R. Allanson. - 1985. Oceanic frontal systems and biological enhancement In: W.R. Siegfried, P.R. Condy and R.M. Laws (eds): Antarctic Nutrient cycles and food webs, pp. 11-21. Springer-Verlag, Berlín.

Metcalf, W.C. - 1969. Dissolved silicate in the deep North Atlantic. Deep-Sea Res., 16: 99-101.

Orsi, A.H.T., T. Whitwort and W.D. Nowlin. - 1995. On the meridional extent and fronts af the Antarctic Circumpolar Current. Deep-Sea Res., 42: 641-673.

Park, Y.H., L. Gamberoni and E. Charriaud. - 1991. Frontal structure and transport of the Antarctic Circumpolar Current in the South Indian sector, $40^{\circ}-80^{\circ}$ E. Mar. Chem., 36: 45-62.

Park, Y.H., L. Gamberoni and E. Charriaud. - 1993a. Frontal structure, water masses, and circulation in the Crozet Basin. J. Geophys. Res., 98: 12361-12385.

Park, Y.H., L. Gamberoni, E. Charriaud and A. Kartavtsett. 1993b. MD68/SUZIL, vol1, Hydrologie. Rapp. Campagnes Mer 93-01. Inst. Français Rech. Tech. Polaires, Paris, 214 pp.

Treguer, P. and P. Le Corre. - 1975. Manuel d'analyse des sels nutritifs dans l'eau de mer. Université de Bretagne Occidentale. Brest, $110 \mathrm{pp}$

Walsh, J.J. - 1971. Relative importance of habitat variables in predicting the distribution of phytoplankton at the ecotone of the Antarctic upwelling ecosystem. Ecol. Monogr., 41: 291-309.

Scient. ed.: C. Pedrós-Alió 